\title{
Large-Scale Anthropological Surveys in Austria-Hungary, 1871-1918
}

\author{
Margit Berner
}

1889: At a joint meeting of the German and Viennese Anthropological Societies, Rudolf Virchow (1821-1902) announces that, in the next twenty years, more study should be devoted to the relations and differences between the inhabitants of Europe, which he regarded to be anthropologically less well studied than non-Europeans. ${ }^{2}$ Like the majority of his colleagues, he rejects the idea that "nationalities" past or present were identical with "races." Peoples of a "pure race" existed only in the distant past, and the nations of Europe are admixtures of those original groups. He professes particular interest in the German and Slavic populations of Germany, Austria-Hungary, and Russia. Russia and Germany intrigue him for their variety and regional differences in human morphology, while the dual monarchy is important, because here "the remnants of old nationalities were of greater purity than elsewhere in Europe." 3 Their persistence would facilitate discovery of the racial ancestry of European peoples generally.

1912: The keynote speech by Felix von Luschan $(1854-1924)^{4}$ at the fortythird meeting of the German Anthropological Society in Weimar makes refer-

1 I would like to thank Paul Weindling and the editors of this volume for useful comments and suggestions and for helping with the correction and editing the final version of the manuscript.

2 Rudolf Virchow, "Die Anthropologie in den letzten 20 Jahren," Mitteilungen der Anthropologischen Gesellschaft in Wien (MAGW) 19 (1889): (68). [numbers in parentheses indicate the pagination of the Sitzungsberichte, as opposed to the essay section of the journal].

3 Ibid., (59).

4 Luschan, since 1872 member of the Viennese Anthropological Society and curator of their collection, graduated in Medicine in Vienna in 1878. In the same year, he set up the ethnographic exhibition for the World's Fair in Paris. In 1882, he became a private lecturer [Privatdozent] in physical anthropology 
ence to Virchow's aspirations, only to regret that they have not been realized. ${ }^{5}$ Luschan stresses the need to improve insight into questions of "fitness" for military service and of "degeneration" through the nascent field of Sozialanthropologie or eugenics, with all its practical uses and theoretical appeal. ${ }^{7}$ Thus, he urges the collection of data on the physical condition of Germans on a large scale, which, if gathered for the army and navy, ${ }^{8}$ could be put to prophylactic use, while statistical profiles of racial "hybrids" would enhance the understanding of physical and mental traits. ${ }^{9}$

1915: The Viennese Anthropological Society initiates studies in prisonerof-war (POW) camps. Research led by Rudolf Pöch (1870-1921) initially aims at investigating the anthropologically less well-known peoples of the Russian Empire who, it is feared, may soon die out under Tsarist Russification. ${ }^{10}$ In the same year, similar research in Germany is initiated by Luschan. ${ }^{11}$ POWs from colonies around the world are seen as offering specialists an opportunity to

in Vienna. In 1885, he took a position as assistant at the Ethnological Museum in Berlin. In Berlin, Luschan acquired the venia legendi in physical anthropology in 1888, and, in 1900, an extraordinary professorship was established there for him. Luschan's chair became a full professorship in 1909. As early as 1891, he had applied for a professorship in anthropology in Vienna, but he never succeeded in founding an anthropological institute. Sergio Sergi, "Felix von Luschan," Rivista Anthropologia 26 (1924-1925): 521-524; Marion Melk-Koch, "Zwei Österreicher nehmen Einfluß auf die Ethnologie in Deutschland: Felix von Luschan und Richard Thurnwald," in Kulturwissenschaft im Vielvölkerstaat, eds. Britta Rupp-Eisenreich and Justin Stagl (Vienna: Böhlau, 1995), 132-140; Benoit Massin, "From Virchow to Fischer: Physical Anthropology and 'Modern Race Theories' in Wilhelmine Germany," in Volksgeist as Method and Ethic: Essais on Boasin Ethnography and the German Anthropological Tradition, ed. George W. Stocking (Madison, WI: University of Wisconsin Press, 1995), 84.

5 Felix von Luschan, "Anthropologie: Rückblicke und Ausblicke; Eröffnungsrede der 43. allgemeinen Versammlung der deutschen Anthropologischen Gesellschaft in Weimar," special issue, Aus der Natur 9 (1912): 1-11.

6 Ibid., 7.

7 Ibid., 6.

8 Ibid., 8.

9 Ibid., 10.

10 Rudolf Pöch, "1. Bericht über die von der Wiener Anthropologischen Gesellschaft in den k.u.k. Kriegsgefangenenlagern veranlaßten Studien," MAGW 45 (1915): 219-235.

11 See the contribution by Britta Lange in this volume. See also Andrew D. Evans, "Anthropology at War: Racial Studies of POWs during World War I," in Worldly Provincialism: German Anthropology in the Age of Empire, eds. H. Glenn Penny and Matti Bunzl (Ann Arbor, MI: University of Michigan Press, 2003), 208209; idem, "Capturing Race: Anthropology and Photography in German and Austrian Prisoner-of-War Camps during World War I," in Colonialist Photogra- 
resolve as yet open questions in anthropology, ${ }^{12}$ including the racial makeup of the peoples of India, the relationship of Berber and Arab peoples, and migrations to Europe from central Asia and the Near East. ${ }^{13}$

These three moments in the history of German-speaking anthropology serve to illustrate the field's main lines of development. From the perspective from within the field itself, it can be said that the interest in the origins of humankind, as well as in the emergence and hierarchical organization of what they called "races" of humanity, had been given additional impetus by the rise of evolutionary theory. Archaeological finds in the latter half of the nineteenth century steered it toward local research and appeared to support the notion that Germanic tribes descended primarily from a blond, long-skulled race, and Slavic tribes from brunette, short-skulled stock. Having mapped distribution of the "types" in Germany and neighboring countries, anthropologists now hoped to unravel their origins. Inquiry into the effects of "interbreeding" in colonial settlements outside Europe was transposed to the mixing of European "tribes." Multiethnic states, such as the Russian Empire and AustriaHungary, with their isolated backwaters as well as regions of intense "mixing," were regarded as invaluable storehouses of information on the racial makeup of European populations. From the perspective of influences outside the immediate realm of scientific inquiry, it can be said that intensifying nationalism and the emergence of eugenics suggested political connotations of notions of race and hybridization that went beyond mere categorization. Critiques of the effects of civilization gave way to politicized questions of the intrinsic constitution and "fitness" of the collective. Thus, the development of the discipline cannot be viewed as linear. It arose from the interplay between scientific inquiry and the search for practical applications, contact between non-European and European peoples, and the rush to study what were perceived as endangered communities in Europe and elsewhere.

Whereas fieldwork overseas was conducted primarily by individuals pursuing more or less their own personal research interests, large-scale domestic data-gathering was seen as potentially being in the national interest and was not only dependent on institutional support from scientific societies and their networks, but also sought government support. The Austro-Hungarian monarchy directly underwrote research into its subjects' varied ethnicity, in most cases by members of the Viennese Anthropological Society. This chapter

phy: Imag(in)ing Race and Place, eds. Eleanor M. Hight and Gary D. Sampson (London: Routledge, 2002), 226-256.

12 Felix von Luschan, “Ein Beitrag zur Völkerkunde im Weltkriege/Einführung in die Grundzüge der Anthropologie," in Hermann Struck, Kriegsgefangene: 100 Steinzeichnungen (Berlin: Reimer, 1917).

13 Ibid., 7, 84-89, 104-109. 
will focus on its attempts to investigate schoolchildren and, less successfully, military recruits. After describing the genesis and objectives of these surveys of race that began in the 1870s, the chapter will explore the nature and extent of nineteenth-century anthropology's influence on the POW studies as well as the differences between the large-scale domestic surveys and those of foreign POWs. While they built on the earlier studies, and the camps were considered a microcosm of Europe just as the Austro-Hungarian Empire had been, the conduct of physical anthropology in the camps was significantly and increasingly influenced by Pöch's field experience outside Europe.

\section{Surveys of the Empire}

Techniques of identification and classification by race changed in the late nineteenth century. Earlier paradigms like that of the highly influential Johann Friedrich Blumenbach (1752-1840) functioned by reference to "typical" individuals, but anthropologists now began measuring large cohorts and comparing data sets. In the place of visual assessments, averages and highest frequencies were used to establish "types."

A central criterion was the cephalic index, the ratio of a skull's length to its width. ${ }^{14}$ For example, the Austrian anatomist Augustin Weisbach (18371914) published measurements of individuals from different races in $1878,{ }^{15}$ incorporating head and body measurements of living people collected during a round-the-world expedition by the frigate Novara between 1857 and 1859 . He distinguished eighteen human varieties according to the cephalic index, the projection of the upper jaw, and the ratio of upper to lower limb length. His stated aim was to obtain a disinterested classification based on anatomy alone, but, perhaps predictably, Europeans occupied the top positions in his hierarchy, with Africans and Sinti and Roma at the bottom of the scale. ${ }^{16}$ Following Anders Retzius's classification of skulls as dolichocephalic (long), brachycephalic (short), or mesocephalic (in between), as well as the division of profiles into orthognathous and prognathous (straight vs. protruding upper jaw), ${ }^{17}$ for example, he reasoned based on his measurements of humans and apes that brachycephalic, prognathous people were closer to primates on

14 Stephen Jay Gould, The Mismeasure of Man, revised and expanded ed. (New York: Norton, 1996).

15 Augustin Weisbach, "Körpermessungen verschiedener Menschenrassen," supplement, Zeitschrift für Ethnologie 9 (1878).

16 Ibid., 7-9.

17 Idem, "Beiträge zur Kenntnis der Schädelformen österreichischer Völker," Wiener Medizinische Jahrbücher 20, no. 1 (1864): 52. 
the scale of human development ${ }^{18}$ (an interpretation which was later found, of course, to be utterly false). Weisbach's European data were collected among the various nationalities under Austro-Hungarian rule in which he came in contact in the course of his military service. During his deployment in Olmütz (Olomouc), he had collected data from soldiers, continuing when he became a senior physician in the military hospital in Istanbul. ${ }^{19} \mathrm{He}$ considered AustriaHungary an ideal venue for the study of national difference, categorizing its nationalities into racial groups, including Germanic, Slavic, and Romanic. ${ }^{20}$ He was convinced that the study of Stämme [tribes] (conceived in physical terms) would reveal typical internal structures of the brain case. Between 1864 and 1867, he published several articles on skull and pelvis measurements, addressing differences between the sexes and various nationalities. ${ }^{21}$

In 1882, Luschan submitted his own hypothesis for a systematic classification by race. ${ }^{22}$ Like Weisbach, he had studied medicine at the Military-Medical Academy Josephinum in Vienna. He had also collected data during his military service, ${ }^{23}$ but, where Weisbach's research conducted for the military had focused on the Empire, Luschan consistently took geographic distribution into account, utilizing and discussing findings in ethnology, archaeology, and linguistics, as well as anatomical data. ${ }^{24}$ To Luschan, races represented variet-

18 Idem, "Körpermessungen verschiedener Menschenrassen," 9.

19 Rudolf Pöch, "Dr. Augustin Weisbach 1837-1914," Wiener Prähistorische Zeitschrift 1 (1914): 143-149; Carl Toldt, "Augustin Weisbach,"MAGW 41 (1911): 9-11; see also Brigitte Fuchs, "Rasse," "Volk," "Geschlecht": Anthropologische Diskurse in Österreich 1850-1960 (Frankfurt a. M.: Campus, 2003), 139-144.

Weisbach, "Beiträge zur Kenntnis der Schädelformen österreichischer Völker," no. 1 (1864): 49-50.

21 Ibid., 49-127; idem, "Beiträge zur Kenntnis der Schädelformen österreichischer Völker," Wiener Medizinische Jahrbücher 20, no. 2 (1864): 33-86, 119-154; idem, "Die Becken österreichischer Völker," Wiener Medizinische Jahrbücher 22, no. 1 (1866): 27-96; idem, "Beiträge zur Kenntnis der Schädelformen österreichischer Völker," Wiener Medizinische Jahrbücher 23, no. 1 (1867): 123-152, 184-224; idem, "Beiträge zur Kenntnis der Schädelformen österreichischer Völker," Wiener Medizinische Jahrbücher 23, no. 2 (1867): 25-72.

22 Felix von Luschan, "Die physischen Eigenschaften der wichtigsten Menschenracen," special issue, Dr. Wittelhöfer's "Wiener Medizinische Wochenschrift" 39-42 (1882): 1-25.

23 During his period as a physician in the occupied area of Bosnia, Luschan arranged archaeological excavations, collected anthropological and ethnographic materials, and gathered anthropometric data on the people. MelkKoch, "Zwei Österreicher," 132-140.

24 Luschan undertook several journeys, amongst them, between 1882 and 1902 to Asia Minor, where he excavated in Sendschirli. Later in 1905, he traveled to South Africa and, in 1914, to the United States. On his journeys, he collected ethnographical "materials" and anthropometric data, as well as photographs 
ies of humans, ${ }^{25}$ and he postulated a correlation of height, brain weight, and intelligence with the capacity for civilization [Kulturfähigkeit]. ${ }^{26}$ While he underlined complexity and opposed broad generalizations, he nonetheless differentiated between civilized people [Kulturvölker] and "lower races." ${ }^{27}$ On the basis of geographical distribution, Luschan distinguished three races defined by typical external morphology as well as anthropometry.

In Luschan's view, a linking of language with physical appearance was unjustified. Peoples like the Basques or those of the Caucasus were the remnants of early immigration-thus their presence in remote regions, difficult to access. ${ }^{28}$ But the local uniqueness of their languages did not entail unique physical characteristics. Citing Johannes Ranke, Felix von Luschan considered the distribution of physical characteristics in Central Europe to be primarily determined by geography, rather than the product of a "specific mixture of peoples." ${ }^{29}$ Racial variation was seen as a function of environmental conditions. He suggested that maps of coloring distribution be made for countries bordering on Germany, eventually to include the entire "white race" and all humankind. ${ }^{30}$

The model for the mapping that Luschan proposed was a large-scale survey of German schoolchildren that had begun in 1871, a year after the founding of the German Society for Anthropology, Ethnology, and Prehistory, the results of which were published by Virchow in 1886 . The original plan had been to include German-speaking Austrians in the German organization, but the Viennese Anthropological Society was founded separately during the same year. It incorporated sections on Racenlehre, Ethnographie, and Urgeschichte [physical anthropology, ethnology, and prehistory]. ${ }^{31}$ At its inaugural meeting, Carl von Rokitansky (1804-1878) emphasized the importance of studying the national "materials" of Austria in light of race: "There is still much work to be done in der österreichischen Racenlehre [Austrian race studies]." 32 The new conception of racial classification demanded robust data from large samples, requiring standardized measurement and description by trained experts. In

and language recordings; Sergi, "Felix von Luschan," 521-524; Melk-Koch, "Zwei Österreicher," 132.

25 Luschan, "Die physischen Eigenschaften," 12.

26 Ibid., 4, 6 .

27 Ibid., 10.

28 Ibid., 23.

29 Ibid., 24.

30 Ibid., 25.

31 Virchow, "Anthropologie in den letzten 20 Jahren," (57).

32 Carl von Rokitansky, "Eröffnungsrede, gehalten in der constituierenden Versammlung der anthropologischen Gesellschaft in Wien am 13. Februar 1870," MAGW 1 (1971): 1-10, esp. 8. 
Austria, as in Germany, special committees were appointed to coordinate work and reconcile the methodology of the different fields. ${ }^{33}$

Virchow reported that, although there were times where their interests did not coincide, the two institutions exchanged information, and several joint meetings were held. ${ }^{34}$ In 1871, the German Society put Virchow in charge of a commission to carry out "a statistical study of skull form all over Germany," 35 but, within a year, it had become apparent that it would be difficult for anthropologists to find sufficient subjects for measurement, living or dead. The commission then put forward the idea that both public schools and the military constituted cross-sections of German society. Children were considered less desirable study objects, since the data they presented was not directly comparable to those obtained from adults. But German military authorities refused to allow data collection during recruitment, arguing that it would take up too much time, while the German states were willing to allow teachers to collect data from pupils. ${ }^{36}$ Criteria were reformulated to permit relatively reliable data-gathering by nonspecialists: ${ }^{37}$ Eye and hair color and height would provide a "picture of the ethnic type" [Völkertypus]..$^{38}$ Assuming the existence of two original "pure races" which in Germany had intermingled and produced a range of types varying from long-skulled, light-skinned, blond, and blueeyed to short-skulled, dark-skinned, brunette, and brown-eyed, the commission sought to determine their geographical distribution, obtaining data that would enable comparison with earlier and later measurements. ${ }^{39}$

Data-gathering took several years, and the Anthropological Society hired the Royal Statistical Bureau to compile the statistics. ${ }^{40}$ Virchow published the

33 MAGW 10 (1880): 67, 73-75; MAGW, 11 (1881): 59-60.

34 Virchow, "Anthropologie in den letzten 20 Jahren," (57).

35 Correspondenz-Blatt der deutschen Gesellschaft für Anthropologie, Ethnologie und Urgeschichte (1871): 53.

36 Correspondenz-Blatt der deutschen Gesellschaft für Anthropologie, Ethnologie und Urgeschichte (1874): 30-40.

37 Andrew Zimmerman, "Anti-Semitism as Skill: Rudolf Virchow's Schulstatistik and the Racial Composition of Germany, "Central European History 32 (1999): 413.

38 Archiv für Anthropologie 5 (1872): 509-512.

39 Correspondenz-Blatt der deutschen Gesellschaft für Anthropologie, Ethnologie und Urgeschichte (1873): 28-29; see also Zimmerman, "Anti-Semitism as Skill," 409-429.

40 Georg Mayr, "Die bayerische Jugend nach der Farbe der Augen, der Haare und der Haut," special issue, Zeitschrift des Kgl. Bayrischen Statistischen Bureau 4 (1875): 21-39; Rudolf Virchow, "Gesammtbericht über die Statistik der Farbe der Augen, der Haare und der Haut der Schulkinder in Deutschland," Correspondenz-Blatt der Deutschen Gesellschaft für Anthropologie, Ethnologie und Urgeschichte 16 (1885): 89-100. 
results, including comparisons with similar studies in Austria, Switzerland, and Belgium, in 1886. ${ }^{41}$ Types and traits were grouped and graphed and their frequencies inscribed on a map of Germany, presenting its geography in terms of the distribution of the two types. Jews were recorded separately, implying that they were a people apart-mostly of the brunette racial type, although 11 percent qualified as blond. Most children displayed ambiguous traits. The study's central finding was that, while the vast majority of the children displayed a mixture of traits, Germans could be viewed as "predominantly" of the blond type ["der herrschende Typus"], while the darker type was "secondary" [Nebentypus]. ${ }^{42}$

Following the German example, the Viennese Anthropological Society set up a commission to study the distribution of the blond and brunette types in Cisleithania (the Austrian part of Austria-Hungary). Initial attempts to collect data in military and educational institutions were unsuccessful. Eventually, in 1880 , the German questionnaire and a standard state questionnaire were used to tally the hair, eye, and skin color of 2.3 million pupils in Austrian elementary schools. Results were compiled by Gustav Adolf Schimmer (1828-1902), a member of the Central Statistical Commission, and published in $1884 .{ }^{43}$ In contrast to the German results, the brunette type predominated. Schimmer concluded that, for the blond type, there was a link between body type and nationality; the lower or higher incidence of blonds coincided with the language borders between Germans and Czechs, Poles and Ruthenians, and Germans and Italians given in Karl Freiherr von Czoernig's (1804-1889) ethnographic maps. ${ }^{44}$ Schimmer discussed the variances among German, German-Czech, and German-Polish school districts in Bohemia, Moravia, and Silesia, drawing special attention to the abundance of blonds in German, German-Czech, and German-Polish schools. Along the language boundary, he found a higher frequency of the brunette type in Czech school districts. ${ }^{45}$

The Austrians structured their study in much the same way as the Germans, with a significant difference: Data on Jewish children was not integrated, but

41 Rudolf Virchow, "Gesammtbericht über die Statistik der Farbe der Augen, der Haare und der Haut der Schulkinder in Deutschland," Archiv für Anthropologie 16 (1886): 275-475.

42 Ibid.; Zimmerman, "Anti-Semitism as Skill."

43 Gustav Adolf Schimmer, "Erhebungen über die Farbe der Augen, der Haare und der Haut bei den Schulkindern Österreichs," MAGW (1884), Supplement I: 8-9, 23.

44 For Czoernig, see also Regina Bendix, "Ethnology, Cultural Reification, and the Dynamics of Difference in the Kronprinzenwerk," in Creating the Other: Ethnic Conflict \& Nationalism in the Habsburg Central Europe, ed. Nancy M. Wingfield (New York: Berghahn, 2003), 149-166, 152-153; Fuchs, "Rasse," "Volk," "Geschlecht," 152-155.

45 Schimmer, "Erhebungen." 
appeared separately. Schimmer reasoned that in Bukovina and Galicia, where "this race still separates itself very strictly ritually and in its way of life and keeps itself pure," the differences between the Christian and Jewish schoolchildren would be considerably more than in countries where "a highly developed Culturleben [cultural life] has already removed these barriers for the most part." ${ }^{\prime 46}$ However, the numbers proved him wrong: The differences between Jewish and Christian children in Galicia and Bukovina were less significant than in Lower Austria, Moravia, and Bohemia, where he had expected more mixing. To resolve the conundrum created by his presumption of a "Jewish type," Schimmer divided Jews into sedentary and nomadic subtypes. In the latter group, the brunette type was then seen to be predominant.

Schimmer also attempted to connect cultural differences, such as language, with physical differences. For Virchow, geographical circumstances were more relevant-thus, his interest in the Austrian regions bordering Germany. He regarded Schimmer's finding of a link between physical "type" and nationality with scepticism, since there were discrepancies between maps of somatic types and those of ethnic groups ${ }^{47}$ But Virchow valued the information that the Austrian study provided on other ethnic groups, particularly on the Slavs. ${ }^{48}$ A study by Ludwig Schneider, a historic preservation officer in Bohemia, analyzed Gustav Adolf Schimmer's data for Bohemia in greater detail and found a more differentiated pattern, correlating the results with archaeological findings from prehistoric times. ${ }^{49}$ An 1878 study recorded hair, eye and skin color in Styria, with the aim of establishing a connection between language and somatic traits, but revealed only minor differences between German-speakers and Slovenes, suggesting to researchers that a considerable number of Germans were of Slavic descent. ${ }^{50}$

In 1881, the Viennese Anthropological Society set up another commission to collect anthropometric data on Austro-Hungarian "races and nations." The anatomist Carl Langer (1819-1887) wrote guidelines for ethnographic research on "Czechoslovak, Magyar, and German Stämme [tribes] (conceived of as ethnicities)" that included measurements of both living subjects and cranial remains. ${ }^{52}$ His recommendations were based on the assumption that

46 Ibid., 23-24.

47 Virchow, "Gesammtbericht," (1886), 374.

48 Ibid., 386.

49 Ludwig Schneider, "Verbreitung des blonden und des brünetten Typus in Böhmen," special issue, Verhandlungen der Berliner Anthropologischen Gesellschaft, Sitzung vom 18.7.1885, 339-353.

50 Christian Promitzer, "The South Slavs in the Austrian Imagination," in Wingfield, Creating the Other, 183-215, esp. 191.

51 MAGW 11 (1881): 59-60.

52 Carl Langer, "Programm für ethnographische Untersuchungen insbesondere auf dem Gebiete Oesterreichs," MAGW 13 (1883): 133-135. 
the territories of nations and those of races were not identical and that nations were not racial units. Modern populations were "racially mixed," meaning that the different European races had interpenetrated each other, but the extent of penetration varied from region to region. Thus, the computation of the arithmetical means of body measurements in an entire nation would not accurately reflect its racial makeup, regardless of sample size. Langer suggested that researchers begin data collection in well-defined regions of relative racial "purity," such as remote steppes and the inaccessible alpine valleys to prove the existence of earlier "racial elements." For populations failing to display a uniform character, he suggested that researchers subdivide it before beginning work at a given nationality's geographic center and continuing toward the periphery. Such studies would require expert knowledge, especially of anatomy, as well as practical competence. He also recommended employing illustrators and photographers. ${ }^{53}$

Austrian anatomists and military personnel carried out several regional studies. Augustin Weisbach and the anatomist Carl Toldt (1840-1920) were the main practitioners of craniometry as well as of measurements on living soldiers, largely in regions then considered Austrian. Heinrich Himmel (1843-1915), an army captain, collected data on recruits during his deployment in Herzegovina. With assistance from military personnel, he measured two hundred and thirty-three soldiers identified as Muslim, Catholic, and Eastern Orthodox, as well as sixty Moravian soldiers from another regiment. ${ }^{54}$ Himmel extended his research to Czernowitz in Bukovina, where he measured Romanians, Ruthenians, and Jews. ${ }^{55}$ A coworker also measured inhabitants of Bukovina. ${ }^{56}$

\section{The Encyclopedia of Empire}

The large-scale surveys of schoolchildren and regional studies of soldiers and local populations were included among the anthropological articles of the Kronprinzenwerk, an illustrated historical and ethnographic encyclopedia

53 Ibid.

54 Heinrich Himmel, "Das Rekrutenmaterial der Herzegowina, Vorlage der Arbeit von Josef Szombathy," MAGW 16 (1886): (67-68); idem, Das Rekrutenmaterial der Herzegowina (unpublished manuscript, Library of the Department of Anthropology, Inv. No. 303).

55 Idem, "Körpermessungen in der Bukowina, Vorlage der Arbeit von Augustin Weisbach,"MAGW 18(1888): (83-84); idem, Das Soldatenmaterial der Bukowina (unpublished manuscript, Library of the Department of Anthropology, Inv. No. 413).

56 MAGW 19 (1889), Jahresbericht: (6). 
formally known as Die österreichisch-ungarische Monarchie in Wort und Bild [The Austrian-Hungarian Monarchy in Words and Pictures]. Under the patronage of Crown Prince Rudolf, it was published in twenty-four volumes between 1886 and 1902. ${ }^{57}$ Members of the Viennese Anthropological Society were on the editorial committee: Ferdinand Andrian-Werburg (1835-1914) for ethnography, Gundacker von Wurmbrand for prehistory, and Franz von Hauer (1822-1899), superintendent of the new Natural History Museum in Vienna, for the natural sciences. ${ }^{58}$ A separate editorial committee was appointed for Hungary. Each Crown land was accorded a separate volume with its own contributors, each himself a representative of that country. Earlier ethnographic schemes, such as that of Archduke Johann Salvator, had been based on analyses of people and nationalities without being structured according to the political units of the Crown lands. ${ }^{59}$

An ethnographic orientation dominated the entire opus. Reinhard Johler has described how the encyclopedia's contents contributed to the implementation and understanding of Austrian ethnography as a discipline: Ethnography emerged as a central political science. One of its objectives was to provide representations of diversity that would help consolidate the Empire. ${ }^{60}$ Earlier assessments that dismissed the Kronprinzenwerk as an apolitical popular journalistic work have been subject to reevaluation. Katherina Weigand, for

57 See Justin Stagl, "The Kronprinzenwerk-Representing the Multi-National State," in Ethnicity, Nation, Culture: Central and East European Perspectives, eds. Bálint Balla and Anton Sterbling (Hamburg: Krämer, 1998), 17-30; idem, "Das 'Kronprinzenwerk': Zur Einführung," in Ethnographie in Serie: Zu Produktion und Rezeption der "Österreichisch-ungarischen Monarchie in Wort und Bild," vol. 28, eds. Jurij Fikfak and Reinhard Johler (Vienna: Veröffentlichungen des Instituts für Europäische Ethnologie), 28-41; Bendix, "Ethnology."

58 Christiane Zintzen, ed., Die österreichisch-ungarische Monarchie in Wort und Bild: Aus dem Kronprinzenwerk des Erzherzog Rudolf (Vienna: Böhlau, 1999), 279.

59 Katharina Weigand, "'Die österreichisch-ungarische Monarchie in Wort und Bild': Ein kulturpolitisches Instrument am Ende des 19. Jahrhunderts," in Fikfak and Johler Ethnographie in Serie, 62-80.

60 Reinhard Johler, "[...] die Lesewelt auffordernd zu einer Wanderung durch weite, weite Lande, zwischen vielsprachigen Nationen, inmitten stets wechselnder Bilder. Zur Geschichte des Monumentalwerkes ‘Die österreichischungarische Monarchie in Wort und Bild,' dargestellt am Beispiel des 1898 erschienen Bandes 'Galizien,'" in Galizien: Ethnographische Erkundung bei den Bojken und Huzulen in den Karpaten; Begleitbuch zur Jahresausstellung '98 im Ethnographischen Museum Schloß Kittsee vom 6. Juni bis 2. November 1998. Kittseer Schriften zur Volkskunde 9, ed. Klaus Beitl (Vienna: 1998), 43-55. 
instance, regards it as an instrument in a policy to create and strengthen patriotism by constructing the monarchy as "total." ${ }^{1}$

With the exceptions of Croatia, Slovenia, and Hungary, one chapter of each volume was dedicated to physical anthropology. Although aimed at a general readership, they were authored by physicians, anatomists, or both, jointly, and reflect the prevailing level of scientific knowledge in the various countries. Compared to other articles, their style and vocabulary can be characterized as more scientific, documenting research results, descriptions of frequencies of observations, measurements, and statistics. Generally, for each Crown land, the physical appearance of its various "ethnic tribes" [Volksstämme] was described in anthropometric terms, such as the cephalic index. Most articles referenced the school study's examination of children's coloring, deploring the lack of measurements of adults and historic and prehistoric skulls. Up to this point, data on prehistoric skulls had been associated with archaeological and historical tribes, and a link between skull shape and coloring could not be verified. Nevertheless, skull forms were assumed to represent racial groups: Blond types were regarded as the offspring of dolichocephalic Germanic tribes and brunettes as stemming from Slavic or other eastern or Mediterranean groups. The large number of hyperbrachycephalic heads-very short and round-was mentioned in each article and ascribed either to an older "race type" or to "mixing." Military statistics on height and fitness were likewise included. Nearly all articles incorporate descriptions of physical appearance, but some also turned to government data on mortality, birth rates, migration, and the frequency of certain diseases and developmental disorders. On occasion, articles added mental characteristics. Drawings illustrated typical inhabitants of each land, but without accompanying maps. Rural life was regarded as beautiful, harmonious, and healthy, while industrialization was associated with deleterious effects on physical appearance and "degeneration."

The Kronprinzenwerk makes plain that anthropologists aspired to map anthropological traits onto current and past populations of the Empire. With the help of history and ethnology, it would be possible to trace racial types in nationalities past and present. The authors hoped to resolve questions about racial constancy and mixing as well as the influences of migration and environment. As conceived, the project would require huge numbers of measurements, and the military was the preferred source. But despite making several attempts, the Anthropological Society did not succeed in collecting sufficient data on the physical appearance of the inhabitants of Austria-Hungary to answer such questions during the nineteenth century.

61 Weigand, "Die österreichisch-ungarische Monarchie." 


\section{National Surveys with "Colonial" Input: Promoting Anthropology at the University}

With the Kronprinzenwerk, it became obvious that no comprehensive survey of the physical makeup of Austria-Hungary's subjects had yet been achieved. The school study remained an interim solution, as it was believed that racial features develop fully only in adulthood. Since it was also believed that racial studies could be best pursued on males, the army was considered the superior site for research. It incorporated all the monarchy's nationalities, and its disciplined ethos ought to permit anthropometry on a large scale. But scientific access to conscripted bodies was not as easy as it seemed. The German Society had also not been successful in gaining access to the military: In his 1886 publication on the school study, Virchow regretted that it had not been possible to overcome objections to systematic research, be it on active-duty soldiers or recruits. He did not detail the reasons for the military's lack of enthusiasm, except to say that the studies would have entailed extraordinary time and effort. ${ }^{62}$ Only in Baden and Bavaria had it been possible to collect data on soldiers. ${ }^{63}$ In 1888 , the Viennese Society established a commission for body measurements of the army, ${ }^{64}$ and, a year later, in cooperation with the German Society, developed a data sheet for measurement of recruits that would allow rigorous comparisons.$^{65}$ But its efforts met with familiar difficulties. Anthropological studies in Bosnia were hindered, and the data collected in Salzburg by Karl Rabl (1853-1917) could not be compiled. The Society hoped for the intervention of the Medical Corps. ${ }^{66}$

With the new century, the two anthropological societies tried again. ${ }^{67}$ Rudolf Martin (1864-1925) developed a new data sheet that was accepted, with some modifications, by the committees of both countries. ${ }^{68}$ But within a few years, the Viennese Society again complained that it had not been possible to

62 Virchow, "Gesammtbericht," (1886), 290.

63 Otto Ammon, Die natürliche Auslese beim Menschen: Auf Grund der anthropologischen Untersuchungen an Wehrpflichtigen in Baden und anderer Materialien (Jena: Fischer, 1893); idem, Zur Anthropologie der Badener: Bericht über die von der anthropologischen Kommission des Karlsruher Altertumsvereins an Wehrpflichtigen und Mittelschülern vorgenommenen Untersuchungen (Jena: Fischer, 1899); Johannes Ranke, Beiträge zur physischen Anthropologie der Bayern (Munich: Theodor Riedel, 1883).

64 MAGW 18 (1888), Ausschusssitzung 13.3.1888: (49).

65 "Resultate der Kommissionsberatthungen," MAGW 19 (1889): (185-187).

66 MAGW 18 (1888), Jahresbericht 14.2.1888: (25).

67 MAGW 33 (1903), Monatsversammlung 10.11.1903: (110-111); MAGW 34 (1904), Jahresversammlung 22.3.1904: (22).

68 MAGW 36 (1906), Monatsversammlung 14.11.1905: (85). 
complete the studies. Explanations ranged from organizational difficulties to the deaths of committee members, but a recurring theme was the lack of an institute of anthropology and ethnology at the university in Vienna. The Society members at work in military surroundings were independent researchers or physicians who only pursued anthropology as a sideline interest. A university institute would centralize and focus their efforts. The Viennese Society had already been promoting the establishment of a chair in anthropology and ethnography at the university for some time. One of their central arguments had been that the dual monarchy, despite its lack of exotic colonies, promised exceptional opportunities for ethnographic and anthropological study of its own diverse nationalities. ${ }^{69}$ But now, complaints surfaced that there was a complete lack of incentives for researchers to undertake anthropological-ethnographic studies, whereas the colonial policies of the Great Powers were regarded as providing their scientists with such incentives. ${ }^{70}$ Although the Society had tried to legitimize the institutionalization of physical anthropology at the university on the basis of racial studies within the monarchy, research outside Europe seems to have been considered more attractive and prestigious.

The turn of the century also saw the publication of novel theories on the racial makeup of Europeans: German and Austrian anthropologists flocked to the classification of the French naturalist Joseph Deniker (1852-1918), who posited six European races. ${ }^{71}$ A 1906 conference in Monaco charged a commission with reconciling craniometry and cephalometry, ${ }^{72}$ and Martin, anthropometry's main spokesman in Germany, published the first comprehensive German anthropological textbook in $1914 .^{73}$ Eugen Fischer (1874-1967) published his book on race mixing in South Africa in 1913, seeing his findings as evidence for Mendelian heredity in humans. ${ }^{74}$ With the emergence of genetics, racial science, and racial or social hygiene as mainstream scientific endeavors, increasing importance was given to the challenge of distinguishing nature from nurture with regard to both physical and mental traits. Alfred Ploetz (1860-1940) founded the Society for Racial Hygiene in 1905, and Eugen Fischer and Felix von Luschan were among its earliest members, later joined by Rudolf Pöch. All subsequently became involved in POW stud-

69 MAGW 39 (1909): (15-18).

70 MAGW 40 (1910), Jahresversammlung 9.3.1910: (19).

71 Joseph Deniker, The Races of Man (London: Walter Scott, 1900).

72 Josef Szombathy, "Die internationale Konferenz über Schädel- und Kopfmessung, Monaco 1906," MAGW 44 (1914): (9-26).

73 Rudolf Martin, Lehrbuch für Anthropologie in systematischer Darstellung mit besonderer Berücksichtigung der anthropologischen Methoden (Jena: Fischer, 1914).

74 Eugen Fischer, Die Rehoboter Bastards und das Bastardisierungsproblem beim Menschen (Jena: Fischer, 1913). 
ies. ${ }^{75}$ The notion that Kulturvölker had deteriorated, for whatever reasons, lent questions of fitness for combat a new significance, encouraging anthropology to see itself no longer as just an inductive or descriptive science, but as an applied technology with political implications. Though nowhere explicitly stated, it appears against this backdrop that the POW studies could also be understood as a possibility to compare the constitution of Germans with their enemies, however, in the final analysis, it was intended to support wider ranging interpretations in the context of racial science.

In 1913, the University of Vienna acquired in Pöch its first associate professor of anthropology and ethnography. He had trained as a physician, taking part in an 1897 expedition to study the plague in Bombay, an experience that seems to have catalyzed his interest in physical anthropology. He began his studies in Berlin with Luschan in 1900. From 1904 to 1906, he undertook an anthropological-ethnographic expedition to Australia and New Guinea. After the Herero and Nama War (1904-1907), Pöch went on an expedition to Southwest Africa from 1907 to $1909 .^{76}$ By 1913, when he became associate professor in Vienna, Pöch was completing a doctoral thesis in physical anthropology with Ranke in Munich, studying natives of New South Wales and crania from Australian aborigines.

Pöch preferred to focus on peoples he regarded as racially pure. His definitions of pure races came from information provided by colonial authorities, but he measured and photographed large numbers of individuals, selecting for further study those about whose purity he had no doubt. ${ }^{77} \mathrm{He}$ did not collect samples solely on the basis of looks, but the final selection was certainly made according to his idea of what looked right. Pöch was also interested in the effects of colonization, suggesting that a way of life to which a people were not "evolutionarily adapted" might cause "degeneration." Aborigines, for example, were not adapted to agricultural labor, and it was causing their decline as a people. Like Fischer, Pöch was intrigued by questions of racial mixing, and his approach similarly makes clear that he regarded mixed-race individuals as superior to indigenous peoples. Fischer had lectured on his research at the Viennese Society in 1910, emphasizing its potential value for race studies and genetics ${ }^{78}$ and suggesting that research on "hybridization" would bring an

75 Paul Weindling, Health, Race and German Politics between National Unification and Nazism, 1870-1945 (Cambridge, UK: Cambridge University Press, 1989).

76 Eugen Oberhummer, "Rudolf Pöch (gestorben am 4. März 1921)," MAGW 51 (1921): 95-104; Fuchs, "Rasse," "Volk," "Geschlecht," 190-211.

77 Rudolf Pöch, Studien an Eingeborenen von Neu-Südwales und an australischen Schädeln (Dissertation, Ludwigs-Maximilians-Universität München, 1913) (Munich: Hamburger, 1915).

78 "Zur Anthropologie und Ethnologie des 'Bastardvolkes' in Deutsch-Südwestafrika," MAGW 40 (1910): (22). 
understanding of ethnology in light of the "struggle of cultures." In his comments on the lecture, Pöch echoed Fischer's view that segregated mixed-race populations in Africa, although they retained numerous aspects of European culture, did not work as hard or as effectively as Europeans. ${ }^{79}$

Although the Viennese Society had a great interest in studying AustriaHungary, the decision to hire Pöch reflected the need to consider interdisciplinary concerns and to favor experience outside Europe. For Toldt, the Society's president, research on hybrid "bastards" was of "great scientific significance," not only for Pöch's current area of interest ("Bushmen"), but for the monarchy itself: "We in Austria live in the midst of Volksstämme who are constantly mixing with each other." ${ }^{80}$ The transposition of the methods and findings of "bastard" studies to the Habsburg monarchy encouraged a hierarchical classification of Europeans by physical criteria which was increasingly linked to cultural differences. Pöch's 1914 obituary for Weisbach, whom he had not known personally, criticized his methodology as inadequate, but saluted his commitment to intensive study of Austro-Hungarian nationalities. Pöch expressed the hope that those studies could be continued with modern methods. ${ }^{81}$

\section{New Research Potential: Studying Captured Soldiers in POW Camps}

A visit to a POW camp in Upper Austria convinced Rudolf Pöch and his fellow Anthropological Society member, the geographer Eugen Oberhummer (1859-1944), of the camps' potential value for anthropological research. ${ }^{82}$ Pöch argued that he could study "material evenly culled from an entire country" in the camps, which was otherwise possible only where conscripts were concentrated in garrisons. ${ }^{83}$ Toldt duly initiated racial studies of the POWs, ${ }^{84}$ with the Viennese Society providing financial support and appointing a committee to organize and prepare them. Additional support came from the Imperial Academy of Sciences and the Imperial War Ministry. The committee included

79 Ibid., (22-23).

80 MAGW 40 (1910), Jahresversammlung 9.3.1910: (18).

81 Pöch, "Dr. Augustin Weisbach"; Rudolf Pöch to Luschan, 6 August 1915, Nachlass Felix von Luschan, Dr. Augustin Weisbach, Staatsbibliothek zu Berlin-Preußischer Kulturbesitz.

82 Oberhummer, "Rudolf Pöch (gestorben am 4. März 1921)."

83 Rudolf Pöch, "3. Bericht über die von der Wiener Anthropologischen Gesellschaft in den k.u.k. Kriegsgefangenenlagern veranlaßten Studien," MAGW 47 (1917): 77-100, quote on p. 80.

84 Carl Toldt, Carl Toldt: Autobiographie (Berlin: Urban \& Schwarzenberg, 1922), 34-35. 
members of previous commissions for racial and national surveys in AustriaHungary, including Carl Toldt and Josef Szombathy (1853-1943), curator of the anthropological-prehistoric collection at the Natural History Museum in Vienna. ${ }^{85}$ From 1915 to 1918, anthropometric measurements of thousands of POWs interned in Austria-Hungary and Germany were carried out by a team led by Rudolf Pöch and his chief assistant Josef Weninger (1886-1959) that eventually included several students. Briefly, Pöch also made ethnographic recordings of songs, even filming dances, but he soon ceded those aspects to the Phonographic Commission of the Academy, preferring to concentrate on his racial researches. ${ }^{86}$

Pöch's example inspired a wave of wartime anthropometric studies in the Austro-Hungarian Empire. The anthropologist Viktor Lebzelter (1889-1936) measured Serbs, Roma, and Sinti while stationed in Krakow. The ethnologist Arthur Haberlandt (1889-1964) measured Albanians in Montenegro and Albania. Georg Kyrle (1887-1937), a geologist and pharmacist who had worked with Rudolf Pöch during 1915, undertook family studies of Wolhynians as commander of an epidemiological laboratory. Pöch extended his own research to women and children by initiating study of Wolhynian families in a refugee camp in Austria. The work performed by his student and later wife Helene Schürer von Waldheim (Hella Pöch, 1893-1976) ${ }^{87}$ can be seen as the first inheritance study in which somatic traits included palm lines. Although she assumed that nutrition, health, and lifestyle also played a role in racial hygiene, they were not analyzed. ${ }^{88}$

85 Pöch, "1. Bericht," 219.

86 Ibid.; idem, "2. Bericht über die von der Wiener Anthropologischen Gesellschaft in den k.u.k. Kriegsgefangenenlagern veranlaßten Studien," MAGW 46 (1916): 107-131; idem, "3. Bericht"; idem, "4. Bericht über die von der Wiener Anthropologischen Gesellschaft in den k.u.k. Kriegsgefangenenlagern veranlaßten Studien," MAGW 48/49 (1918/1919): 146-161; Margit Berner, "From 'Prisoners of War Studies' to Proof of Paternity: Racial Anthropologists and the Measuring of 'Others' in Austria," in "Blood and Homeland": Eugenics and Racial Nationalism in Central and Southeast Europe 1900-1940, eds. Marius Turda and Paul Weindling (Budapest: Central European University Press, 2006), 41-54; idem, "Forschungs-'Material' Kriegsgefangene: Die Massenuntersuchungen der Wiener Anthropologen an gefangenen Soldaten 1915-1918," in Vorreiter der Vernichtung: Eugenik, Rassenhygiene und Euthanasie in der österreichischen Diskussion vor 1938; Zur Geschichte der NS-Euthanasie in Wien Teil III, eds. Heinz Eberhard Gabriel and Wolfgang Neugebauer (Vienna: Böhlau, 2005), 167-198; idem, "Die 'rassenkundlichen' Untersuchungen der Wiener Anthropologen in Kriegsgefangenenlagern 1915-1918," Zeitgeschichte 30 (2003): 124-136.

87 Ibid.

88 AÖAW, Subventionen, math.-nat., K.7, Konv. '1918' No. 250/1918, Bericht; Berner, "Forschungs-'Material' Kriegsgefangene, 184. 
Pöch differentiated between Volk and race. In his view, a multitude of "recent ethnic groups" had been formed from a few originally widespread races; the degree of mixing was visible as racial difference. ${ }^{89} \mathrm{Up}$ to this point, he followed Langer's guidelines for ethnographic research. ${ }^{90}$ What was new was his understanding of race in the light of Mendelian genetics. Recessive genes could explain why racial traits assumed to be static did not correspond to field observations. Fischer's studies had shown that race per se was not inherited; instead, individual traits were passed down, so that mixing created "hybrids" rather than new races. ${ }^{11}$ Thus, within a given population, inadvertent backcrossing might produce individuals who represented pure types. Researchers strove to locate accidental specimens of long-vanished pure races in an approach that reprised nineteenth-century research on nationalities in Austria-Hungary. Many considered pure races to possess an aesthetic advantage. Pöch found Bashkir and Tatar individuals to be "disharmonious and ugly" in comparison with the "uniform, pure" Mongolian or Finnish types who he postulated had provided their constituent "racial elements." 92

In line with Langer, Pöch created sample groups in the camps by selecting a quorum of individuals he found to be representative of some particular type, ${ }^{93}$ then recording personal data for each prisoner, including his parents, tribal affiliation, and places of birth and residence with region and district, to allow the creation of maps. Increasingly, physical and mental features overlapped. Pöch insisted that the character of a Volk was determined by psychological traits and talents which were just as hereditary as physical traits. ${ }^{94}$ Physical anthropology in Austria, especially craniometry, was no longer content to remain inductive, but aspired to offer wide-ranging interpretations and evaluations of "races" and peoples, which were nonetheless heavily influenced by common stereotypes and prejudices.

The camps were Pöch's first foray into racial surveys which included European subjects. His earlier studies had concentrated on non-Europeans. The POW studies betray continuity in organization and research design, as well as protagonists, with earlier anthropology. Sponsorship by the Viennese Anthropological Society, endeavors to obtain support from official authorities, appointments, and committee work were traditions of long standing. The standard form resembled the military's own assessments of physical fitness as well

89 Rudolf Pöch, "Neue anthropologische Fragestellungen," Mitteilungen der Geographischen Gesellschaft in Wien 62 (1919): 193-209.

90 Langer, "Programm," 133-134.

91 Pöch, "Neue anthropologische Fragestellungen."

92 Ibid., 197-198.

93 Idem, "3. Bericht," 78-79.

94 Idem, "Neue anthropologische Fragestellungen," 197-198. 
as procedures originally designed for large-scale investigations on recruits that had never been carried out. The Viennese Anthropological Society stressed with pride that the founding of the university department was the main factor behind the success of the POW studies in Austria. ${ }^{95}$ Pöch's position, his commitment to the project, and his intermittent exemptions from military service allowed him to concentrate on research, and he managed to examine POWs on a vast scale.

Pöch's initial design for the POW research was similar to that of his earlier ethnographic and racial field studies, but his interest shifted, and he came to concentrate on racial studies alone. He began the project under the influence of his own past expeditions, with the idea of investigating prisoners from the multiethnic Russian Empire. Race and subrace were terms integral to his taxonomy, entailing discussions of origin and demarcation. Constructed or "ideal" racial types provided the framework for investigations aimed at defining racial features and types ${ }^{96}$ - with Mendelian heredity allowing "pure" traits to survive crossbreeding, so that even "mixed" peoples could take their places in racial hierarchies. The fact that he extended his research to include Africans suggests that the project had taken on a life of its own: With so much emphasis on the once-in-a-lifetime opportunity to collect "material," data-gathering came to overshadow the evaluation and publication of results. Among other things, Pöch apparently hoped to supply the teaching collection of his new institute with many plaster heads. It is doubtful that participation was entirely voluntary; his own hesitations regarding the casting of facial features and complaints from Egon von Eickstedt (1892-1965) about the reluctance of prisoners in German camps to submit to measurements are well documented. ${ }^{97}$

Although information on the POW studies was exchanged between Germany and Austria, the Viennese Society began the project without a mutual cooperative arrangement. ${ }^{98}$ Only after Pöch expanded the studies to include Africans did he work together with Luschan..$^{99}$ Luschan's interest stemmed from his desire to answer open questions with a geographically oriented catalog of the world's races. ${ }^{100} \mathrm{He}$ assigned his student Egon von Eickstedt and the

95 MAGW 46 (1916): (3).

96 Peter Weingart, Jürgen Kroll, and Kurt Bayertz, Rasse, Blut und Gene: Geschichte der Eugenik und Rassenhygiene in Deutschland (Frankfurt a. M: Suhrkamp, 1996), 355-360.

97 Evans, "Anthropology at War," 209, 217-222.

98 Anthropologische Gesellschaft archive, Protokoll der Ausschuß-Sitzung am 11. Juni 1915.

99 Letters from Pöch to Luschan on 6 March 1917, 24 May 1917, and 27 February 1918, Nachlass Felix von Luschan, Staatsbibliothek zu Berlin-Preußischer Kulturbesitz.

100 See also Luschan, "Ein Beitrag zur Völkerkunde im Weltkriege." 
anthropologist Otto Reche (1879-1966) to a parallel German POW project. Reche began his study with ethnic groups from central Asia, and Eickstedt with Indians, Turks, and Asians. Each developed his own interests, Reche shifting his attention to western Europeans while Eickstedt went on to measure Scots, Irish, English, Ukrainians, Poles, ethnic Russians, and others. ${ }^{101}$

\section{Conclusion: Three Phases in Viennese Anthropology}

After Pöch's death in 1921, Weninger led the evaluation and publication of the data, mostly based on student theses, ${ }^{102}$ and was appointed to a professorship in 1927.

In 1938, as head of the Institute of Anthropology in Vienna, Weninger sketched three stages of development that had characterized the Institute's first twenty-five years, ${ }^{103}$ based on the central themes of Pöch's career. The initial phase had been the collection of skeletal remains from non-European indigenous populations on expeditions to Australia, New Guinea, and Africa; the second phase turned to materials acquired in the POW camps during World War I, regarded as high-quality source data for general and systematic anthropology. Family and inheritance research-the "erbbiologische Richtung"constituted the third phase with its serial studies of children and families from Austrian populations and a research project on ethnically German families in Romania as well as various persons examined in the context of paternity assessments for some courts in Vienna. ${ }^{104}$ Weninger considered the three stages not merely in terms of current research: Their accumulated data and materials would serve as important resources to establish an institutional archive for

101 Evans, "Anthropology at War," 209, 217-222.

102 Berner, "Die 'rassenkundlichen' Untersuchungen"; idem, "Forschungs'Material' Kriegsgefangene."

103 Josef Weninger, "25 Jahre Anthropologisches Institut an der Universität Wien," MAGW 68 (1938): 191-205.

104 Idem, "25 Jahre Anthropologisches Institut"; Maria Teschler-Nicola, "Volksdeutsche and Racial Anthropology in Interwar Vienna: The 'Marienfeld Project,'" in "Blood and Homeland": Eugenics and Racial Nationalism in Central and Southeast Europe 1900-1940, eds. Marius Turda and Paul Weindling (Budapest: Central European University Press, 2006), 55-82; Margit Berner, "Die Bedeutung der biometrischen Erfassungsmethode in der österreichischen Anthropologie in der ersten Hälfte des 20. Jahrhunderts," in Eugenik: Biopolitische Methoden und Strukturen von 1900-1945, eds. Gerhard Baader, Veronika Hofer, and Thomas Mayer (Vienna: Czernin, 2007), 239-256; Fuchs, "Rasse," "Volk," "Geschlecht." 
purposes of continued research and teaching. ${ }^{105}$ Weninger noted a trajectory through the three stages from non-Europeans to Europeans as subjects. Via the study of eastern Europeans and Asian Russians, the ultimate focus had shifted, he argued, to Austrians and other German-speakers. But his argument is false. Pöch's studies outside Europe were completed before he acquired a university position, and the activities of the Viennese Anthropological Society are disregarded entirely. It had pursued studies of local populations since its inception.

Shifts in the focus of anthropological inquiry have been addressed in numerous recent historical studies that illuminate continuities and ruptures with the aim of improving our understanding of the role of anthropology in National Socialist Germany. ${ }^{106}$ The studies posit a break with a fin-de-siècle liberal-humanist tradition in reaction to various sociopolitical forces and shifts in scientific paradigms, culminating in an illiberal paradigm conducive to National Socialist cooptation. This narrative is often assumed to be true for Austria as well, as German physical anthropology played a leading role in the discipline and anthropology of the Reich, the dual monarchy, and Germanspeaking Switzerland, which were seen as forming, in effect, one "scientific nation." ${ }^{107}$ But while this may be true for certain aspects of research, methodology especially, to assume that it is also true for the sociopolitical context underestimates Austria-Hungary's and later Austria's cultural, historical, and geopolitical particularities, as well as the not insignificant role played by the interests of individual researchers.

105 Weninger, "25 Jahre Anthropologisches Institut," 196, 199.

106 Robert Proctor, "From Anthropology to Rassenkunde in the German Anthropological Tradition," in Bones, Bodies, Behavior: Essays on Biological Anthropology, History of Anthropology 5, ed. George W. Stocking (Madison, WI: University of Wisconsin Press, 1988), 138-179.

107 Massin, "From Virchow to Fischer," 83. 
